\title{
KARAKTERISTIK DAN DAMPAK SIKLON TROPIS YANG TUMBUH DI SEKITAR WILAYAH INDONESIA
}

\author{
Oleh \\ Dewi Surinati ${ }^{1)}$ dan Dwi Ayu Kusuma ${ }^{2)}$
}

\begin{abstract}
CHARACTERISTICS AND IMPACTS OF TROPICAL CYCLONES GROWING AROUND INDONESIAN TERRITORY. Tropical cyclone is a cyclonic originates from tropical oceans and driven principally by heat transfer from the ocean. Tropical cyclone is an atmospheric phenomenon characterized by the emergence of low air pressure that triggers the occurrence of strong winds due to the process of heat transfer from the equator to the latitude. This phenomenon can not be prevented, so that it has great potential to impact on the damage in the area it through. Tropical cyclones can be characterized through their life cycle, scale of power and how it impacts in the area it through. The Cempaka and Dahlia tropical cyclone occuring in 2017 greatly influenced territory of Indonesia. The effect of the cyclone causes extreme weather in Indonesia, especially in areas close to where cyclones are formed.
\end{abstract}

\section{PENDAHULUAN}

Cuaca di Indonesia dipengaruhi oleh beberapa faktor, antara lain adalah pengaruh lokal, angin moonson, angin pasat, zona awan penghasil hujan yang berada di sekitar equator/ITCZ ( Inter Tropical Convergence Zone), fenomena El Nino dan La Nina, fenomena dipole mode serta terakhir depresi dan siklon tropis (Putra \& Khomaruddin, 2004). Terkait dengan faktor siklon tropis, Indonesia secara teori tidak dapat dilintasi oleh siklon tropis karena karakteristik fisis siklon tropis akan selalu menjauhi ekuator. Meskipun demikian, bibit-bibit siklon tropis untuk basin Samudera India bagian Tenggara banyak yang berasal dari wilayah selatan Indonesia. Lebih lanjut, walaupun siklon tropis bergerak

1) Pusat Penelitian Oseanografi-LIPI menjauhi Indonesia, namun dampak tidak langsung (remote impact) dari siklon tropis tetap terjadi di Indonesia. Dampak tidak langsung tersebut di antaranya adalah daerah pertemuan angin yang dapat menyebabkan hujan dengan intensitas lebat hingga sangat lebat, dan dampak tidak langsung lainnya adalah angin yang bertiup kencang (Radjab, 2017).

Siklon tropis merupakan fenomena atsmosfer yang ditandai munculnya tekanan udara rendah yang memicu terjadinya angin yang kencang akibat proses perpindahan panas dari daerah khatulistiwa menuju garis lintang. Dampak siklon tropis sangat dirasakan oleh daerah pesisir dan daratan baik berupa meningkatnya curah hujan, bencana 
banjir hingga kerusakan infrastruktur. Dampak yang ditimbulkan masing masing siklon terhadap curah hujan berbedabeda tergantung karakteristik siklon dan kondisi lingkungannya (Prasetya et al., 2014).

Siklon tropis ternyata dapat membawa dampak positif, yaitu menjadi salah satu faktor pemicu terjadinya pengadukan vertikal dan upwelling yang menyebabkan meningkatnya kesuburan perairan. Penelitian dilakukan di Laut Arafura dan sekitarnya pasca terjadinya siklon tropis LAM yang menerjang perairan Arafura dan pantai Queensland Australia pada tanggal 19 Februari 2015. Hasil analisis data konsentrasi klorofil-a komposit 8 harian satelit Aqua Modis menunjukkan daerah yang dilalui oleh siklon tropis LAM mengalami peningkatan kesuburan namun dengan respon yang berbeda pada masing-masing area pengamatan (Susilo \& Hadianti, 2015).

\section{SIKLON TROPIS}

Siklon tropis merupakan salah satu fenomena skala regional yang muncul di samudera tropis (Prasetya et al., 2014). Sedangkan daerah tropis merupakan daerah yang lebih intensif menerima radiasi matahari, sehingga suhu permukaan laut di daerah tropis lebih hangat dari pada di daerah kutub. Daerah kutub memiliki suhu permukaan laut yang rendah, karena intensitas matahari yang didapat lebih sedikit dibandingkan daerah tropis. Ketika suhu permukaan laut tinggi, maka terbentuk pusat tekanan rendah yang dapat memicu terjadinya siklon tropis yang dimulai dengan gangguan tropis lalu depresi tropis, badai tropis selanjutnya terjadi siklon tropis (Asrianti et al., 2013).

Siklon tropis merupakan badai dengan kekuatan yang besar, dengan rata-rata radius siklon tropis mencapai 150 hingga $200 \mathrm{~km}$. Siklon tropis terbentuk di atas lautan luas yang umumnya mempunyai suhu permukaan air laut hangat, lebih dari $26,5^{\circ} \mathrm{C}$. Angin kencang yang berputar di dekat pusatnya mempunyai kecepatan angin lebih dari $63 \mathrm{~km} / \mathrm{jam}$. Siklon tropis dianalogikan sebagai mesin carnot. Ukuran dari energi dapat dihitung melalui total entropis per unit masa udara dan energi mekanik dari siklon tersebut. Siklus Carnot merupakan proses tertutup. Selama siklus tersebut berlangsung, entropi diperoleh dekat permukaan laut dengan suhu yang hangat, dan entropi dapat hilang di dekat awan bagian atas karena suhu awan semakin dingin (Asrianti et al., 2013).

Siklon tropis dikenal dengan berbagai istilah di muka bumi, yaitu "badai tropis" atau "typhoon" atau "topan" jika terbentuk di Samudra Pasifik Barat, "siklon" atau "cyclone" jika terbentuk di sekitar India atau Australia, dan "hurricane" jika terbentuk di Samudra Atlantik. Badai tropis merupakan kata lain siklon tropis. Hurricane merupakan sebutan bagi siklon tropis di Samudra Pasifik Selatan, Samudra Pasifik Timur Laut dan Samudra Atlantik Utara yang mempunyai kecepatan angin maksimum lebih dari 64 knot (119 km/jam). Sedangkan typhoon atau topan adalah 
hurricane yang terjadi di Samudra Pasifik Barat Laut (TCWC Jakarta, 2009a).

Masa hidup suatu siklon tropis rata-rata berkisar antara 3 hingga 18 hari. Energi siklon tropis diperoleh dari lautan hangat. Oleh karena itu, siklon tropis akan melemah atau punah ketika bergerak dan memasuki wilayah perairan yang dingin atau memasuki daratan (Syaifullah, 2015).
Daerah pertumbuhan siklon tropis (Prasetya et al., 2014) mencakup Atlantik Barat, Pasifik Timur, Pasifik Utara bagian Barat, Samudera Hindia bagian Utara dan Selatan, Australia dan Pasifik Selatan (Tabel 1). Sebagian besar siklon tropis yaitu sekitar 2/3 kejadian terjadi di belahan bumi bagian utara. Siklon tropis terbentuk pada lintang antara $10^{\circ}$ dan $20^{\circ}$ dari ekuator, hanya sekitar $13 \%$ siklon tropis yang tumbuh di atas daerah lintang $20^{\circ}$, sedangkan di daerah lintang rendah $\left(0^{\circ}-10^{\circ}\right)$ siklon tropis jarang terbentuk.

Tabel 1. Daerah pertumbuhan siklon tropis di seluruh dunia.

\begin{tabular}{|c|c|c|}
\hline No. & Nama Daerah Pertumbuhan & Luasan Wilayah \\
\hline 1 & Atlantik Utara & $\begin{array}{l}\text { Samudra Atlantik Utara, Laut Karibia dan } \\
\text { Teluk Meksiko }\end{array}$ \\
\hline 2 & Pasifik Timur Laut & Amerika Utara hingga $180^{\circ} \mathrm{BT}$ \\
\hline 3 & Pasifik Barat Laut & $\begin{array}{l}\text { Sebelah Barat } 180^{\circ} \mathrm{BT} \text {, termasuk Laut } \\
\text { Cina Selatan }\end{array}$ \\
\hline 4 & Hindia Utara & Teluk Benggala dan Laut Arab \\
\hline 5 & Hindia Selatan & $\begin{array}{l}\text { Samudra Hindia Selatan sebelah Barat } \\
100^{\circ} \mathrm{BT}\end{array}$ \\
\hline 6 & Hindia Tenggara / Australia & Bumi Belahan Selatan $100-142^{\circ}$ BT \\
\hline 7 & Pasifik Barat Daya / Australia & $\begin{array}{l}\text { Bumi Belahan Selatan sebelah Timur } 142^{\circ} \\
\text { BT }\end{array}$ \\
\hline
\end{tabular}

Adanya pengaruh gaya Coriolis menyebabkan terbentuknya pusaran awan yang bergerak ke arah barat atau barat laut. Oleh karena gaya Coriolis ditentukan oleh posisi lintang tempat, maka gerak siklonik tidak dapat atau sulit terjadi di daerah yang berada di dekat ekuator. Umumnya pembentukan siklon tropis ini efektif pada daerah lintang di atas $10^{\circ}$ Lintang Utara maupun Lintang Selatan. Oleh sebab itu, wilayah
Indonesia bukan merupakan daerah pembentukan badai/siklon tropis tetapi posisi geografisnya berbatasan dengan daerah pembentukan dan lintasan siklon tropis (Haryani \& Zubaidah, 2012).

\section{Proses Terbentuknya Siklon Tropis}

Siklon tropis terbentuk disebabkan oleh beberapa hal, diantaranya adalah (BMKG dalam Syaifullah, 2015): 
1. Suhu permukaan laut sekurangkurangnya $26.5^{\circ} \mathrm{C}$ hingga kedalaman 60 meter.

2. Kondisi atmosfer tidak stabil, memungkinkan terbentuknya awan Cumulonimbus. Tipe awan ini, yang merupakan awan-awan guntur, merupakan indikator konvektif kuat.

3. Atmosfer yang relatif lembab di ketinggian sekitar $5 \mathrm{~km}( \pm 15$ ribu kaki). Ketinggian ini merupakan atmosfer paras menengah, yang apabila dalam keadaan kering tidak dapat mendukung bagi perkembangan aktivitas badai guntur di dalam siklon.

4. Berada pada jarak setidaknya sekitar $500 \mathrm{~km}$ dari katulistiwa. Meskipun memungkinkan, siklon jarang terbentuk di dekat ekuator.

5. Gangguan atmosfer di dekat permukaan bumi berupa angin yang berpusar yang disertai dengan pumpunan angin (konvergensi).

6. Perubahan kondisi angin terhadap ketinggian tidak terlalu besar. Perubahan kondisi angin yang besar akan mengacaukan proses perkembangan badai guntur.

\section{Struktur SiklonTropis}

Struktur umum yang dimiliki oleh siklon tropis adalah sebagai berikut (Pustekkom, 2005):

Low Pressure (Tekanan Permukaan Rendah): siklon tropis berputar di sekitar daerah bertekanan udara permukaan rendah.
Dinding mata: menyerupai pita melingkar di sekitar mata yang memiliki intensitas angin dan konveksi panas paling tinggi. Pada siklon tropis, kondisi pada dinding matalah yang paling berbahaya.

Mata: siklon tropis kuat seperti hurricane memiliki mata yang berbentuk lubang melingkar di pusat sirkulasinya. Cuaca pada mata umumnya tenang dan tidak berawan.

Inti hangat: uap air yang naik ke atmosfir yang dingin akan mengembun dan melepaskan panas. Panas buangan tersebut didistribusikan secara vertikal pada bagian inti siklon tropis yang menyebabkannya terasa hangat

7. Aliran keluar (outflow): pada bagian atas siklon tropis, angin bergerak keluar dari pusat badai tropis dengan arah putaran berlawanan dengan siklon, sedangkan pada bagian bawah angin berputar kuat, melemah seiring dengan pergerakan naik dan akhirnya berbalik arah.

\section{Siklus Hidup Siklon Tropis}

Siklon tropis memiliki siklus hidup mulai dari proses pembentukannya hingga saat melemah, siklus ini hampir sama dengan siklus cuaca. Siklus hidup siklon tropis dapat dibagi menjadi empat tahapan (Syaifullah, 2015), yaitu:

I. Tahap Pembentukan: biasanya ditandai dengan adanya gangguan atmoster, dapat dilihat dari satelit satelit cuaca, gangguan ini ditandai 
dengan wilayah konvektif dengan awan-awan cumulonimbus. Pusat sirkulasi seringkali belum terbentuk, namun kadang kala sudah nampak pada ujung sabuk perawanan yang membentuk spiral.

II. Tahap Belum Matang: pada tahap ini wilayah konvektif kuat terbentuk lebih teratur membentuk sabuk perawanan melingkar (berbentuk spiral) atau membentuk wilayah yang bentuknya relatif bulat. Intensitasnya meningkat secara terus menerus ditandai dengan tekanan udara permukaan yang turun mencapai kurang $<1000 \mathrm{mb}$, serta kecepatan angin maksimum yang meningkat hingga mencapai gale force wind (kecepatan angin $\geq 34$ knot atau 63 $\mathrm{km} / \mathrm{jam})$. Angin dengan kecepatan maksimum terkonsentrasi pada cincin yang mengelilingi pusat sirkulasi. Pusat sirkulasi terpantau jelas dan mulai tampak terbentuknya mata siklon.

III. Tahap Matang: pada tahap matang, bentuk siklon tropis cenderung stabil. Sirkulasi siklonik dan wilayah dengan gale force wind meluas, citra satelit cuaca menunjukkan kondisi perawanan teratur dan lebih simetris. Pada siklon tropis yang lebih kuat dapat jelas terlihat adanya mata siklon. Fenomena ini ditandai dengan wilayah bersuhu paling hangat di tengah-tengah sistem perawanan dengan angin permukaan yang tenang dan dikelilingi oleh dinding perawanan konvektif tebal di sekelilingnya (dinding mata).
Kecuali jika siklon tropis berada di wilayah yang sangat mendukung perkembangannya, tahap matang biasanya hanya bertahan selama kurang lebih 24 jam sebelum intensitasnya mulai melemah.

IV. Tahap Pelemahan: pada tahap punah, pusat siklon yang hangat mulai menghilang, tekanan udara meningkat dan wilayah dengan kecepatan angin maksimum meluas dan melebar menjauh dari pusat siklon. Tahap ini dapat terjadi dengan cepat jika siklon tropis melintas di wilayah yang tidak mendukung bagi pertumbuhannya, seperti misalnya memasuki wilayah perairan lintang tinggi dengan suhu muka laut yang dingin atau masuk ke daratan. Dari citra satelit dapat terlihat jelas bahwa wilayah konvektif siklon tropis tersebut berkurang, dan sabuk perawanan perlahan menghilang. Waktu rata-rata yang dibutuhkan sebuah siklon tropis dari mulai tumbuh hingga punah adalah sekitar tujuh hari, namun variasinya bisa mencapai 1 hingga 30 hari.

\section{Skala Kekuatan Siklon Tropis}

Siklon tropis yang terjadi pada umumnya memiliki skala kekuatan yang berbeda. Menurut Syaifullah (2015), skala yang umum digunakan untuk menggambarkan kekuatan dari siklon tropis yang terjadi adalah Skala SaffirSimpson (Tabel 2). 
Tabel 2. Skala Saffir-Simpson untuk siklon tropis.

\begin{tabular}{|c|c|c|c|}
\hline $\begin{array}{c}\text { Kategori Saffir- } \\
\text { Simpson }\end{array}$ & $\begin{array}{c}\text { Kecepatan } \\
\text { angin maks. } \\
\left(\mathbf{m s} \mathbf{-}^{-1}, \mathbf{k t}\right)\end{array}$ & $\begin{array}{c}\text { Tek. udara } \\
\text { Minimum (mb) }\end{array}$ & $\begin{array}{c}\text { Strom surge } \\
(\mathbf{m}, \mathbf{f t})\end{array}$ \\
\hline 1 (Minimal) & $\begin{array}{c}33-42 \mathrm{~m} / \mathrm{s} \\
{[64-83 \mathrm{kt}]}\end{array}$ & $>=980 \mathrm{mb}$ & $\begin{array}{c}1.0-1.7 \mathrm{~m} \mathrm{[3-} \\
5 \mathrm{ft}]\end{array}$ \\
\hline 2 (Moderat) & $43-49[84-96]$ & $979-965$ & $1.8-2.6[6-8]$ \\
\hline 3 (Ekstentif) & $\begin{array}{c}50-58[97- \\
113]\end{array}$ & $964-945$ & $\begin{array}{c}2.7-3.8[9- \\
12]\end{array}$ \\
\hline 4 (Ekstrim) & $\begin{array}{c}59-69[114- \\
135]\end{array}$ & $944-920$ & $\begin{array}{c}3.9-5.6[13- \\
18]\end{array}$ \\
\hline 5 (Katastropik) & $>69[>135]$ & $<920 \mathrm{mb}$ & $>5.6[>18]$ \\
\hline
\end{tabular}

\section{DAMPAK SIKLON TROPIS}

Siklon tropis menimbulkan dampak yang sangat besar pada tempat-tempat yang dilaluinya, karena ukurannya yang sangat besar serta angin kencang dan gumpalan awan yang dimilikinya. Dampak siklon tropis bisa berupa angin kencang, hujan deras yang terus menerus, bahkan berharihari yang dapat mengakibatkan terjadinya banjir, gelombang tinggi, dan gelombang badai (storm surge). Dampak siklon tropis di laut akan menimbulkan gelombang tinggi, hujan deras disertai angin kencang, mengganggu pelayaran internasional dan berpotensi untuk menenggelamkan kapal. Siklon tropis bisa memutar air sehingga akan menimbulkan gelombang laut yang sangat tinggi. Dampak siklon tropis di daratan dapat merusak atau menghancurkan kendaraan, bangunan, jembatan dan benda-benda lain, mengubahnya menjadi puing-puing beterbangan yang mematikan karena angin kencang dan badai yang dihasilkan. Gelombang badai (storm surge) atau peningkatan tinggi permukaan laut akibat siklon tropis merupakan dampak yang paling buruk yang dapat mencapai daratan. Gelombang badai (storm surge) atau peningkatan tinggi permukaan laut akibat siklon tropis merupakan dampak yang paling buruk yang mencapai daratan (Syaifullah, 2015).

Keterkaitan antara munculnya siklon tropis di Samudera India sebelah selatan dan barat daya Benua Maritim Indonesia dengan kejadian gelombang tinggi di perairan selatan Indonesia, dari lautan di sebelah selatan Jawa sampai Nusa Tenggara Timur (Jawa, Bali, Lombok, Sumba, Sumbawa, dan Flores dan terjadinya angin 
kencang (puting beliung) memang belum dapat diungkapkan secara kuantitatif, namun secara kualitatif hal-hal tersebut menunjukkan keterkaitan yang cukup signifikan (Suryantoro, 2008).

\section{Dampak Langsung}

Pengertian dari dampak langsung siklon tropis adalah dampak yang ditimbulkan oleh siklon tropis terhadap daerah-daerah yang dilaluinya. Hal ini dapat berupa gelombang tinggi, gelombang badai yang berupa naiknya tinggi muka laut, seperti air pasang tinggi yang datang tiba-tiba, hujan deras serta angin kencang (BMKG, 2015). Contoh ketika suatu wilayah di Indonesia mengalami dampak langsung keberadaan siklon tropis adalah ketika terjadi peristiwa langka yaitu tumbuh siklon tropis Kirrily di atas Kepulauan Kai, Laut Banda, pada 27 April 2009. Kirrily menyebabkan hujan lebat dan storm surge di wilayah ini. Tercatat puluhan rumah rusak dan puluhan lainnya terendam, jalan raya rusak, dan gelombang tinggi terjadi dari 26 hingga 29 April. Curah hujan per 24 jam yang tercatat di Tual adalah sebanyak $20 \mathrm{~mm}, 92 \mathrm{~mm}$ dan 193 $\mathrm{mm}$, masing-masing untuk tanggal 27, 28 dan 29 April 2009 (TCWC, 2009b).

Indonesia bukan merupakan daerah lintasan siklon tropis, namun demikian keberadaan siklon tropis di sekitar Indonesia, terutama yang terbentuk di sekitar Pasifik Barat Laut, Samudra Hindia Tenggara dan sekitar Australia akan mempengaruhi pembentukan pola cuaca di Indonesia. Perubahan pola cuaca oleh adanya siklon tropis inilah yang kemudian menjadikan siklon tropis memberikan dampak tidak langsung terhadap kondisi cuaca di wilayah Indonesia.

Wilayah Indonesia memang bukan merupakan daerah pembentukan badai/ siklon tropis tetapi posisi geografisnya berbatasan dengan daerah pembentukan dan lintasan siklon tropis. Badai/siklon tropis tidak hanya berdampak terhadap daerah lintasannya secara langsung, tetapi berpengaruh pula terhadap kondisi cuaca di sekitarnya. Oleh karena itu, siklon tropis berpengaruh terhadap kondisi cuaca di wilayah Indonesia dan dapat terjadi di luar periode yang semestinya. Jadi meskipun Indonesia bukan negara sebagai lintasan siklon tropis namun ada beberapa siklon tropis yang melintas di Indonesia dan memberikan dampak tidak langsung terhadap kondisi cuaca di wilayah Indonesia. Kejadian siklon tropis NATHAN yang terbentuk di Laut Coral pada 10 Maret 2015 menyebabkan dampak tidak langsung terhadap kondisi cuaca di wilayah Indonesia, yaitu tinggi gelombang laut dengan ketinggian 3 meter di Laut Arafuru (TCWC Jakarta, 2015).

\section{Dampak tidak langsung}

Dampak tidak langsung atas adanya siklon tropis dapat berupa berbagai hal, diantaranya yaitu (Haryani \& Zubaidah, 2012):

1). Daerah pumpunan angin. Siklon tropis yang terbentuk di sekitar perairan sebelah utara maupun 
sebelah barat Australia sering kali mengakibatkan terbentuknya daerah pumpunan angin di sekitar Jawa atau Laut Jawa, NTB, NTT, Laut Banda, Laut Timor, hingga Laut Arafuru. Pumpunan angin inilah yang mengakibatkan terbentuknya lebih banyak awan konvektif penyebab hujan lebat di daerah tersebut. Jika dilihat dari citra satelit, daerah pumpunan angin terlihat sebagai daerah memanjang yang penuh dengan awan tebal yang terhubung dengan perawanan siklon tropis, sehingga terlihat seolah-olah siklon tropis tersebut mempunyai ekor. Itulah sebabnya daerah pumpunan angin ini seringkali disebut sebagai ekor siklon tropis.

2). Daerah belokan angin. Adanya siklon tropis di perairan Samudra Hindia Tenggara menyebabkan terbentuknya daerah belokan angin di sekitar Sumatera bagian Selatan atau Jawa bagian Barat. Daerah belokan angin ini juga dapat mengakibatkan terbentuknya lebih banyak awanawan konvektif penyebab hujan lebat di daerah tersebut.

3). Daerah defisit kelembaban Bersamaan dengan adanya siklon tropis di perairan sebelah utara Sulawesi atau di Laut Cina Selatan seringkali teramati bersamaan dengan berkurangnya curah hujan di wilayah Sulawesi bagian utara atau Kalimantan. Meskipun belum ada penelitian lebih lanjut, namun ditengarai bahwa fenomena ini disebabkan karena siklon tropis tersebut menyerap persediaan udara lembab yang terdapat dalam radius tertentu di sekitarnya, termasuk yang terkandung di atmosfer di atas Kalimantan dan Sulawesi bagian utara sehingga di wilayah ini justru udaranya kering dan kondisi cuacanya cenderung cerah tak berawan.

\section{SIKLON TROPIS YANG TUMBUH DI SEKITAR WILAYAH INDONESIA}

Sejak berdirinya Pusat Peringatan Dini Siklon Tropis BMKG (Tropical Center Warning Center/TCWC) pada 24 Maret 2008, terpantau sudah lima kali siklon tropis terjadi di wilayah Indonesia (Gambar 1). Siklon tropis tersebut adalah siklon tropis Durga di perairan barat daya Bengkulu (22-25 April 2008) dengan kecepatan putaran $11 \mathrm{~km} / \mathrm{jam}$, siklon tropis Anggrek di perairan barat Sumatera (30 Oktober - 4 November 2010) dengan kecepatan putaran siklon sebesar $110 \mathrm{~km} /$ jam, siklon tropis Bakung di perairan barat daya Sumatera (11-13 Desember 2014) dengan kecepatan siklon sebesar $75 \mathrm{~km} / \mathrm{jam}$, siklon tropis Cempaka di perairan selatan Jawa (26-29 November 2017) dengan kecepatan $60-90 \mathrm{~km} / \mathrm{jam}$ dan siklon tropis Dahlia yang terjadi di perairan selatan Bengkulu (27 November - 2 Desember 2017) dengan kecepatan 60-130 km/jam (Kurniawan, 2017). 


\section{Siklon tropis yang ditemukan di wilayah Indonesia}

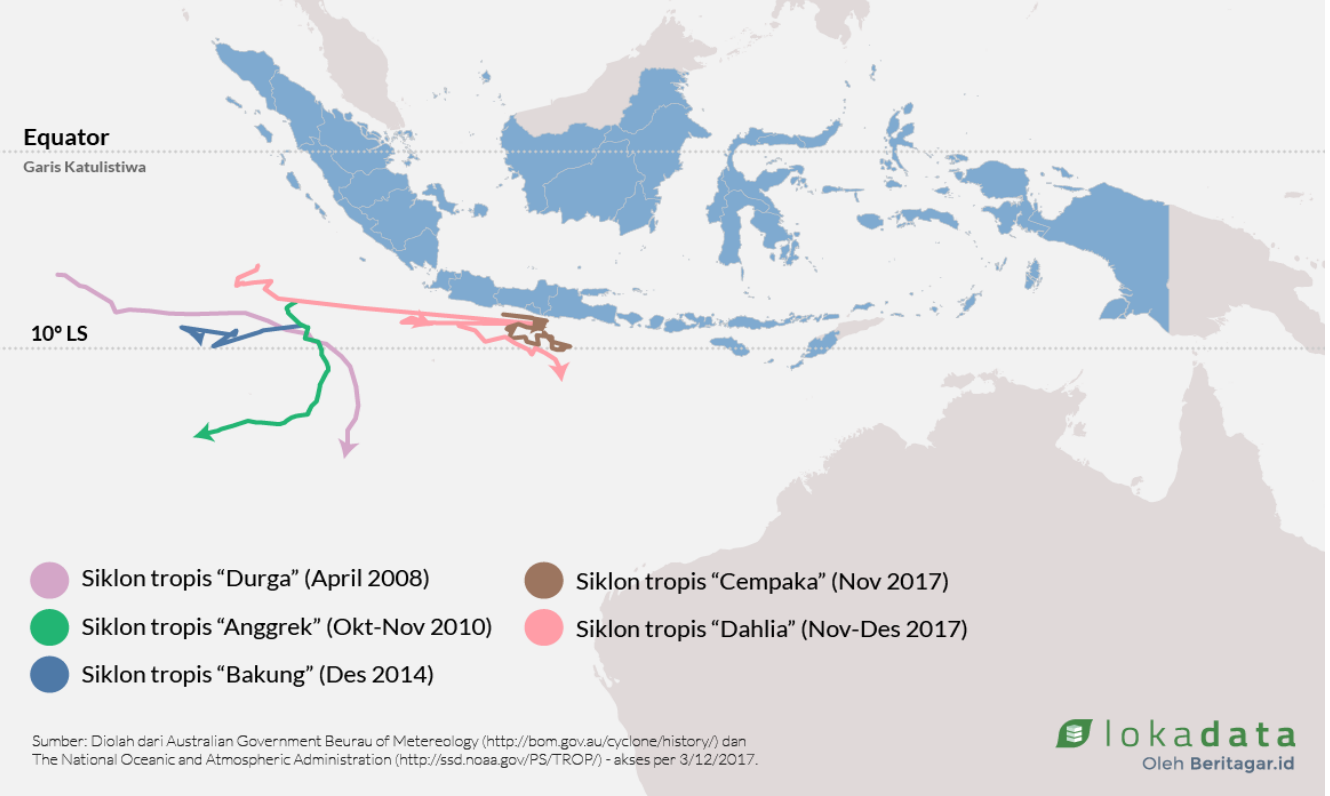

Gambar 1. Siklon tropis yang pernah terjadi di Indonesia (Islahuddin, 2017).

Berbeda dari 3 siklon sebelumya, siklon tropis Cempaka dan Dahlia adalah sebuah anomali. Siklon tropis pada umumnya tidak terbentuk di posisi kurang dari $10^{\circ}$ Lintang Utara dan Selatan, atau dalam radius sekitar $1100 \mathrm{~km}$ dari garis khatulistiwa. Namun keduanya terjadi di bawah $10^{\circ}$ Lintang Utara dan Selatan datang di luar rentang kejadian-kejadian sebelumnya dan dalam waktu berdekatan bahkan pada waktu yang bersamaan dalam hitungan hari. Menurut Profesor Meteorologi dan Klimatologi BPPT, Edvin Aldrian, kemungkinan penyebab terjadinya kedua siklon ini adalah dampak pemanasan global (Islahuddin, 2017).
Dampak siklon tropis Cempaka lebih terasa karena posisinya yang paling dekat dengan daratan (Gambar 2). Perubahan pola cuaca seperti hujan lebat dan angin kencang di sekitar lintasan siklon ini menyebabkan longsor, banjir, pohon dan baliho tumbang, gelombang tinggi, aktivitas penerbangan dan pelayaran terganggu serta membahayakan aktivitas di sekitar pesisir pantai akibat pasang (Arjawinangun, 2017). Gelombang laut di perairan Jawa bagian selatan dan Samudera Hindia mencapai 4-6 meter akibat pengaruh Siklon Cempaka menyebabkan beberapa jadwal pelayaran dibatalkan, selain itu nelayan yang ingin melaut juga tidak berani melaut (Kurniawan, 2017). 


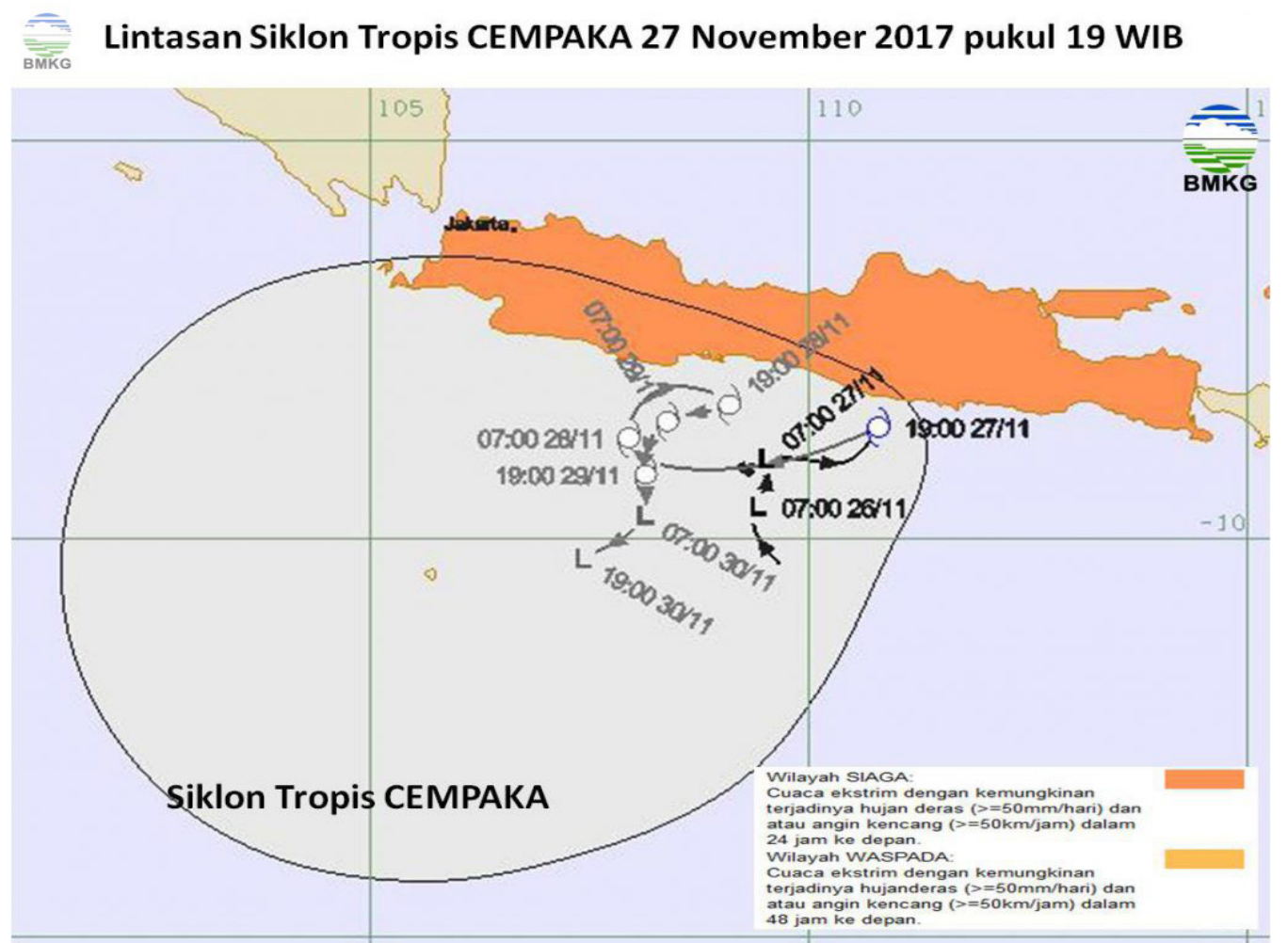

Gambar 2. Lintasan siklon tropis Cempaka 27 November 2017 (Kurniawan, 2017).

Siklon tropis terakhir yang terjadi di Indonesia tahun 2017 adalah siklon tropis Dahlia. Siklon ini merupakan siklon kedua yang terjadi di perairan Bengkulu. Sebelumnya terjadi di bagian barat daya namun yang kedua di bagian selatan. Siklon ini memiliki kecepatan putaran 60-130 km/jam, Meskipun lebih besar kecepatan putaran dari siklon ini namun lokasi terjadinya jauh dari daratan sehingga tidak begitu terasa dampak yang dialami oleh daratan Tumbuhnya siklon tropis Cempaka dan Dahlia dalam waktu yang hampir bersamaan dan dengan posisi yang begitu dekat dengan wilayah Indonesia memperkuat dugaan bahwa saat ini telah terjadi perubahan karakteristik pertumbuhan siklon tropis secara global (Radjab, 2017). Hal tersebut merupakan tantangan bagi para peneliti di bidang atmosfer untuk lebih memahami perubahan pola pertumbuhan siklon tropis.

\section{PENUTUP}

Siklon tropis merupakan fenomena meteorologis yang sangat potensial menimbulkan dampak kerusakan pada daerah yang dilaluinya. Kekuatan alam pada siklon tropis begitu besar dan tak ada upaya manusia yang mampu mencegah atau menghilangkan badai tropis. Wilayah Indonesia umumnya menerima dampak tidak langsung pada perubahan kondisi 
cuaca. Oleh karena itu, diperlukan kajian lebih lanjut mengenai karakteristik dan dampak yang ditimbulkan oleh siklon tropis terutama di wilayah Indonesia.

\section{DAFTAR PUSTAKA}

Arjawinangun, K. B. 2017. Timbulkan Bencana, Ini Penjelasan Mengenai Siklon Tropis Cempaka. https://nasional. sindonews.com/. Diakses pada tanggal 9 Januari 2018.

Asrianti, P., A. Bey dan Y. Ilhamsyah. 2013. Kajian beberapa karakteristik siklon tropis (Kasus topan Choi-Wan dan Nida di Lautan Pasifik Utara bagian Barat). Depik, 2(3): 154-161.

BMKG. 2015. Dampak Siklon Tropis. http://web.meteo.bmkg.go.id. Diakses pada tanggal 9 Januari 2018.

Haryani, N. S. dan A. Zubaidah. 2012. Dinamika siklon tropis di Asia Tenggara menggunakan data penginderaan jauh. Teknologi, 29 (324): 54-58.

Islahuddin. 2017. Cempaka dan Dahlia, Anomali Siklon Tropis Indonesia. https://beritagar.id. Diakses tanggal 9 Januari 2018.

Kurniawan, T. 2017. Siklon Tropis "CEMPAKA" Lahir, Siaga Cuaca Ekstrem 3 Hari ke Depan. $\quad$ http://www.bmkg. go.id/press-release/. Diakses pada tanggal 9 Januari 2018.
Prasetya, R., As'ari dan W. Dayantolis. 2014. Analisis dampak siklon tropis Nangka, Parma dan Nida pada distribusi curah hujan di Sulawesi Utara. Jurnal Fisika dan Aplikasinya, 10 (1): 1-9.

Pustekkom. 2005. Badai Tropis. http:// idkf.bogor.net/yuesbi/e-DU. KU/edukasi.net/Fenomena. Alam/Badai/all.html. Diakses pada 9 Januari 2018.

Putra, D. dan M. R. Khomarudin. 2004. Depresi dan siklon tropis pengaruhi cuaca Indonesia. Berita Inderaja, 3 (5): 16-20.

Radjab, A. F. 2017. Dahlia, Siklon tropis kelima yang tumbuh di sekitar wilayah Indonesia Refleksi 10 Tahun Tropical Cyclone Warning Centre Jakarta. http://www.bmkg.go.id/ artikel/?id=7d5m2014112cudaz4956. Diakses tanggal 24 Januari 2018.

Suryantoro, A. 2008. Siklon Tropis di selatan dan barat daya Indonesia dari pemantauan satelit TRMM dan kemungkinan kaitannya dengan gelombang tinggi dan puting beliung. Majalah Sains dan Teknologi Dirgantara, 3 (1): 21-32.

Susilo, E. dan S. Hadianti. 2015. Peningkatan kesuburan perairan Laut Arafura dan sekitarnya Pascasiklon tropis Lam. Jurnal Sain dan Teknologi, 10 (1): 1-9.

Syaifullah, M. D. 2015. Siklon tropis, 
karasteristik dan pengaruhnya di wilayah Indonesia pada tahun 2012. Jurnal Sains dan Teknologi Modifikasi Cuaca, 16 (2): $61-71$.

TCWC Jakarta. 2009a. Siklon Tropis, Badai Tropis, Hurricane \& Typhoon. http://meteo.bmkg. go.id/siklon/learn/05/id. Diakses pada tanggal 9 Januari 2018.
TCWC Jakarta. 2009b. Siklon Tropis Kirrily. http://maritim.bmg. go.id/cyclones. Diakses pada tanggal 9 Januari 2018.

TCWC Jakarta. 2015. Siklon Tropis Nathan. http://maritim.bmkg. go.id/siklon. Diakses tanggal 9 Januari 2018. 